correlated the changes in impedance values with alterations in the thoracic fluid volume due to pulmonary or cardiac problems. It is suggested that the measurement of T.E.I. is a promising method for the early detection of increased pulmonary fluid volume but that it needs further objective verification in man.

This study was supported by the All India Institute of Medical Sciences, the Directorate General Armed Forces Medical Services, and the Indian Council of Medical Research, New Delhi.

We are grateful to Lt.-Gen. S. N. Chatterjee, Director-General Armed Forces Medical Services, and Lt.-Gen. Ved Prakash, Director Medical Services (Army), and their staff for ungrudging support during all phases of the study.

\section{References}

Allison, R. D., Holmes, E. L., and Nyboer, J. (1964). Gournal of Applied Physiology, 19, 166

Bhatia, M. L., et al. (1969). British Medical fournal, 2, 551.

Bhatia, M. L., et al. (1972). In Advances in Medicine, ed. R. Vishwanathan, p. 466. Bombay, Association of Physicians of India.

Hurtado, A. (1964). In Handbook of Physiology, Section 4, ed. D. B. Dill, E. F. Adolph, and C. G. Wilber, p. 849. Washington, American Physiological Society.

Pomerantz, M., Delgado, P., and Eiseman, B. (1970). Annals of Surgery, 171, 686.

Roy, S. B., et al. (1968). Nature, 217, 1177.

Roy, S. B., et al. (1969). British Heart fournal, 31, 52.

Van De Water, J. M., et al. (1970). Fournal of Thoracic and Cardiovascular Surgery, 60, 641.

Van De Water, J. M., et al. (1973). Chest, 64, 597.

\title{
Hypouricaemia and Proximal Renal Tubular Dysfunction in Acute Myeloid Leukaemia
}

\author{
M. AFZAL MIR, I. W. DELAMORE
}

British Medical fournal, 1974, 3, 775-777

\section{Summary}

Two patients with acute myeloid leukaemia developed hypouricaemia during the period of their illness. Renal clearance studies showed that the hypouricaemia was associated with an increased urate clearance, renal aminoaciduria, and an episodic increase in phosphate clearance. These findings together with an inadequate suppression of urinary urate excretion after the administration of pyrazinamide suggest proximal tubular dysfunction affecting reabsorption of a wide variety of substances. Ten more patients with acute leukaemia were studied and the results indicate that this lesion develops in a large proportion of patients with acute myeloid leukaemia.

\section{Introduction}

An increase in the serum urate level is a common finding in acute leukaemia and lymphoma (Weisberger and Perksy, 1953; Gold and Fritz, 1957; Kritzler, 1958). Hypouricaemia is an unexpected development in diseases characterized by an increase in uric acid production. The case reports of two patients with acute myeloid leukaemia in whom serum uric acid concentration fell below $2 \mathrm{mg} / 100 \mathrm{ml}$ during the course of their illness are presented. Renal clearance studies and amino-acid chromatography showed proximal tubular dysfunction with some features normally seen in association with the adult Fanconi syndrome (Leaf, 1966).

\section{Methods}

Inorganic phosphorus was estimated by the method of Gomorri (1942) using $p$-dimethylaminophenol sulphate as reducing agent. Uric acid and creatinine concentrations were estimated in a Technicon AutoAnalyzer. Paper chromatography was

\footnotetext{
University Department of Clinical Haematology, Manchester Royal Infirmary, Manchester M13 9WL

M. AFZAL MIR, M.R.C.P., D.C.H., Registrar

I. W. DELAMORE, PH.D., F.R.C.P., Physician in Charge
}

performed on the original urine and the extent of aminoaciduria was assessed by visual comparison of the specks with the known spots of various amino-acids. Plasma amino-acid levels were determined by ion-exchange chromatography (Thomas, 1970). Three-hour clearances were performed before and after the administration of pyrazinamide to assess the tubular reabsorption of urate. A high intake of oral fluids was maintained to facilitate spontaneous voiding. Urinary and serum lysozyme concentrations were determined by the turbidimetric method of Parry et al. (1965). Other investigations were performed by standard laboratory methods.

\section{Case Reports}

CASE 1

A 58-year-old woman was admitted to hospital with pallor and moderate hepatosplenomegaly. Haematological studies showed a white cell count of $2,800 / \mathrm{mm}^{3}$ ( $15 \%$ were blast cells), a haemoglobin level of $9 \cdot 1 \mathrm{~g} / 100 \mathrm{ml}$, and a platelet count of $91,000 / \mathrm{mm}^{3}$. A marrow aspirate was hypercellular with $90 \%$ myeloblasts. Serum albumin was $3.5 \mathrm{~g} / 100 \mathrm{ml}$, serum globulin $3.9 \mathrm{~g} / 100 \mathrm{ml}$, serum vitamin $B_{12}$ $277 \mathrm{pg} / \mathrm{ml}$, serum calcium $9.6 \mathrm{mg} / 100 \mathrm{ml}$, and serum inorganic phosphorus $3.4 \mathrm{mg} / 100 \mathrm{ml}$. Serum and urinary muramidase (lysozyme) concentrations were $4.2 \mu \mathrm{g} / \mathrm{ml}$ (normal 3-13 $\mu \mathrm{g} / \mathrm{ml}$ ) and $2.5 \mu \mathrm{g} / \mathrm{ml}$ (normal $<2 \mu \mathrm{g} / \mathrm{ml}$ ) respectively. The blood urea was $28 \mathrm{mg} / 100 \mathrm{ml}$, and three daily serum urate estimations ranged from 4.6 to $5.2 \mathrm{mg} / 100$ $\mathrm{ml}$ (average $4.9 \mathrm{mg} / 100 \mathrm{ml}$ ). Serum transaminases, bilirubin, alkaline phosphatase, and electrolytes were normal. A 24-hour phosphate clearance was $9 \mathrm{ml} / \mathrm{min}$ with a phosphate clearance to creatinine clearance ratio of $0 \cdot 11$ (normal $<0.2$; Nordin and Fraser, 1960). There was no giucosuria, no Bence Jones proteinuria, and the urinary amino-acid chromatographic pattern was normal.

A five-day course of cytotoxic therapy consisting of a single intravenous administration of daunorubicin $(1.5 \mathrm{mg} / \mathrm{kg}$ body weight $)$ and five daily intravenous injections of cytarabine $(2 \mathrm{mg} / \mathrm{kg}$ body weight) was begun on the third day in hospital. Serum urate was $4 \mathrm{mg} / 100 \mathrm{ml}$ and fell to $1.3 \mathrm{mg} / 100 \mathrm{ml}$ two days after the second course of chemotherapy. The results of urate and creatinine clearance studies are shown in table I. Serum calcium was $8.6 \mathrm{mg} / 100 \mathrm{ml}$ and serum inorganic phosphorus $2 \cdot 2 \mathrm{mg} / 100 \mathrm{ml}$. A 24-hour phosphate clearance was $45 \mathrm{ml} / \mathrm{min}$ with a phosphate clearance to creatinine clearance ratio of 0.95 . There was no glucosuria. Paper chromatography showed a generalized aminoaciduria. The arterial blood $\mathrm{pH}$ was $7 \cdot 44$ and serum bicarbonate $28 \mathrm{mEq} / \mathrm{l}$. An acid load of $0.1 \mathrm{~g} / \mathrm{kg}$ body weight of ammonium chloride produced a minimum urinary $\mathrm{pH}$ of 5.3 (normal $\mathrm{pH}<5.3$; Wrong and Davies, 1959). Serum potassium fell to $3 \cdot 2$ $\mathrm{mEq} / \mathrm{l}$. The mean daily potassium output was $42 \mathrm{mEq}$ against an intake of $48 \mathrm{mEq}$. 

TABLE I-Results of Creatinine and Urate Clearance Studies in Two Patients with Acute Myeloid Leukaemia. Control Values are Means ( \pm S.D.) derived from
Seven Subjects

\begin{tabular}{|c|c|c|c|c|c|c|c|}
\hline & \multirow{2}{*}{ Control Values } & \multicolumn{3}{|c|}{ Case 1} & \multicolumn{3}{|c|}{ Case 2} \\
\hline & & On Admission & After Therapy & After Remission & On Admission & After Therapy & After 10 Weeks \\
\hline $\begin{array}{l}\text { Serum Level }(\mathrm{mg} / 100 \mathrm{ml}): \\
\text { Urate } \\
\text { Creatinine } \\
\text { Blood urea }(\mathrm{mg} / 100 \mathrm{ml}) \\
\text { Urinary excretion: } \\
\text { Creatinine }(\mathrm{g} / \mathrm{i} \mathrm{hr}) \\
\text { Urate }(\mathrm{mg} / \mathrm{min}) \\
\text { Clearance }\left(\mathrm{ml} / \mathrm{min} / 1.73 \mathrm{~m}^{2}\right) \text { : } \\
\text { Creatinine } \\
\text { Urate } \\
\text { Filtered Urate }(\mathrm{mg} / \mathrm{min}) \\
\text { Cur } / \text { Ccr } \times 100 \\
\text { UurV } \times 100 / \mathrm{Fur} \\
\text { UurV }\end{array}$ & $\begin{array}{c}5.5 \pm 1.5 \\
1.02 \pm 0.09 \\
15-40 \\
1.03 \pm 0.02 \\
0.49 \pm 0.0004 \\
88 \cdot 16 \pm 5.1 \\
9.2 \pm 1.1 \\
10 \cdot 71 \pm 1 \cdot 07 \\
9 \cdot 7-11 \\
8.8-14\end{array}$ & $\begin{array}{c}4 \cdot 8 \\
1 \cdot 0 \\
28 \\
1 \cdot 10 \\
0 \cdot 42 \\
81 \\
8 \cdot 3 \\
5 \cdot 4 \\
10 \cdot 2 \\
7 \cdot 7\end{array}$ & $\begin{array}{l}1 \cdot 3 \\
0 \cdot 8 \\
8 \\
0.56 \\
0 \cdot 30 \\
47 \\
24 \\
0 \cdot 61 \\
51 \\
49\end{array}$ & $\begin{array}{c}5 \cdot 0 \\
0 \cdot 9 \\
32 \\
0 \cdot 72 \\
0 \cdot 60 \\
83 \\
7 \cdot 8 \\
4 \cdot 0 \\
9 \cdot 3 \\
9 \cdot 2\end{array}$ & $\begin{array}{l}2 \cdot 5 \\
0 \cdot 8 \\
20 \\
1 \cdot 18 \\
0 \cdot 75 \\
95 \\
32 \\
2 \cdot 3 \\
51 \\
32\end{array}$ & $\begin{array}{c}1 \cdot 7 \\
0 \cdot 7 \\
26 \\
1 \cdot 9 \\
0 \cdot 80 \\
203 \\
52 \\
3 \cdot 4 \\
25 \\
11\end{array}$ & 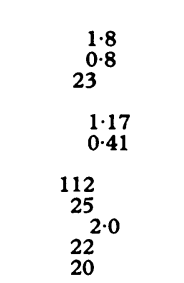 \\
\hline
\end{tabular}

$\mathrm{Cur} / \mathrm{Ccr}=$ Urate/creatinine. UurV/Fur $=$ excreted urate/filtered urate.

TABLE II-Serum and Urine Values in Case 2 before and after Pyrazinamide $3 \mathrm{~g}$ orally

\begin{tabular}{l|c|c}
\hline & Before & After \\
\hline Serum uric acid $(\mathrm{mg} / 100 \mathrm{ml})$ & 1.6 & 1.5 \\
Urinary excretion $(\mathrm{mg} / \mathrm{min}):$ & 0.75 & 0.34 \\
Urate & 1.1 & 0.9 \\
Creatinine & 54 & 25 \\
Cearance $\left(\mathrm{ml} / \mathrm{min} / 1.73 \mathrm{~m}^{2}\right):$ & 134 & 98 \\
Urate & & \\
Creatinine &
\end{tabular}

During the next 18 days serum urate ranged from 1 to $2 \cdot 1 \mathrm{mg} / 100 \mathrm{ml}$. Daily urate and creatinine clearance studies showed a persistently high urate clearance. The phosphate clearance fluctuated between 6 and $42 \mathrm{ml} / \mathrm{min}$ but remained below $10 \mathrm{ml} / \mathrm{min}$ after the 30 th day in hospital.

A bone marrow remission was achieved in the sixth week. The ratio of the excreted urate to the filtered urate (UurV $\times 100 /$ Fur) fell from $49 \%$ to $9 \cdot 2 \%$ after remission and the serum uric acid level increased to $5 \mathrm{mg} / 100 \mathrm{ml}$ (table I). The urinary amino-acid chromatographic pattern returned to normal.

\section{CASE 2}

A 50-year-old woman was admitted with weakness and marked hepatomegaly. Initial investigations showed a haemoglobin level of $7 \mathrm{~g} / 100 \mathrm{ml}$ and a white cell count of $7,200 / \mathrm{mm}^{3}$ with $34 \%$ blast cells. A marrow specimen contained $60 \%$ myeloblasts. Serum albumin was $3.8 \mathrm{~g} / 100 \mathrm{ml}$., serum globulin $3.3 \mathrm{~g} / 100 \mathrm{ml}$, and blood urea $20 \mathrm{mg} / 100$ $\mathrm{ml}$ with a 24-hour phosphate clearance of $6 \mathrm{ml} / \mathrm{min}$. Serum calcium was $9.6 \mathrm{mg} / 100 \mathrm{ml}$ and serum phosphate $3.7 \mathrm{mg} / 100 \mathrm{ml}$. Serum electrolytes, bilirubin, alkaline phosphatase, and transaminases were within normal limits. A urinalysis of a freshly voided specimen showed a $\mathrm{pH}$ of $5,1 \%$ sugar, and a normal amino-acid chromatographic pattern. The 24 -hour urinary protein excretion was $185 \mathrm{mg}$ and immunoelectrophoresis did not show the presence of Bence Jones protein. The fasting blood sugar level was $165 \mathrm{mg} / 100 \mathrm{ml}$ and three determinations of serum uric acid ranged from 2.5 to $3.5 \mathrm{mg} / 100 \mathrm{ml}$.
Additional investigations showed a serum muramidase concentration of $23 \mu \mathrm{g} / \mathrm{ml}$, a urinary muramidase concentration of $1 \mu \mathrm{g} / \mathrm{ml}$, and a diabetic glucose tolerance curve.

Three days after the first course of cytotoxic therapy serum urate fell to $1.7 \mathrm{mg} / 100 \mathrm{ml}$, serum calcium to $8.8 \mathrm{mg} / 100 \mathrm{ml}$, and serum inorganic phosphorus to $2.7 \mathrm{mg} / 100 \mathrm{ml}$, and a 24 -hour phosphate clearance increased to $30 \mathrm{ml} / \mathrm{min}$ with a phosphate clearance to creatinine clearance ratio of $0 \cdot 14$. Paper amino-acid chromatography now showed the presence of a generalized aminoaciduria and the 24-hour urinary protein excretion reached a maximum of $1.2 \mathrm{~g}$, with a predominant electrophoretic mobility in the albumin and $\alpha_{2}$-globulin regions. The arterial blood $\mathrm{pH}$ was 7.42 and the urine $\mathrm{pH}$ after an acid load was $5 \cdot 1$. Plasma bicarbonate was $26 \mathrm{mEq} / \mathrm{l}$. The urate and creatinine clearance data are shown in table $I$.

The effect of pyrazinamide was studied and the results are shown in table II. Plasma amino-acid concentrations were found to be within normal limits. The mean daily urinary potassium was $98 \mathrm{mEq}$ against a mean intake of $57 \mathrm{mEq} /$ day.

She was followed up as an outpatient for 18 weeks and repeated estimations of serum urate ranged from 0.8 to $1.8 \mathrm{mg} / 100 \mathrm{ml}$. The ratio of the excreted urate to that of the filtered urate remained high (table I) but phosphate clearance showed wide fluctuations from $32 \mathrm{ml} / \mathrm{min}$ in the 14 th week to $8 \mathrm{ml} / \mathrm{min}$ in the 16th week. A generalized aminoaciduria was found to be present on each visit. The administration of pyrazinamide produced only a $34 \%$ reduction (normal $>80 \%$; Steele and Rieselbach, 1967) in urate excretion in the 14th week.

\section{OTHER CASES}

The data from these two patients suggested an impairment in renal tubular reabsorption of urate, phosphate, and amino-acids. Ten consecutive patients with acute leukaemia were studied to investigate whether proximal tubular dysfunction occurred as a part of the disease. Urate clearance was found to increase in all the 10 patients. The serum uric acid level increased in two patients with acute lymphoblastic leukaemia and fell in the other eight patients with acute myeloid leukaemia (table III). Hypouricaemia developed in two of these patients (cases 5 and 11). A variable increase in phosphate clearance occurred in all patients after antileukaemic therapy.

TABLE III-Two Sets of Renal Clearance Data (before and after CytotoxicTherapy) for each of 10 Patients with Acute Leukaemia

\begin{tabular}{|c|c|c|c|c|c|c|c|}
\hline \multirow{2}{*}{ Case No. } & \multirow{2}{*}{$\begin{array}{c}\text { Diagnosis } \\
\text { (Acute } \\
\text { Leukaemia) }\end{array}$} & \multirow{2}{*}{$\begin{array}{l}\text { Days after } \\
\text { Diagnosis }\end{array}$} & \multirow{2}{*}{$\begin{array}{c}\text { Serum Urate } \\
(\mathrm{mg} / 100 \mathrm{ml})\end{array}$} & \multirow{2}{*}{$\begin{array}{l}\text { Blast Cell Count } \\
\times 10^{3}\end{array}$} & \multirow{2}{*}{$\underset{(\mathrm{mg} / \mathrm{min})}{\text { Urinary Urate }}$} & \multicolumn{2}{|c|}{ Clearance $\left(\mathrm{ml} / \mathrm{min} / 1.73 \mathrm{~m}^{2}\right)$} \\
\hline & & & & & & Urate & Creatinine \\
\hline 3 & Myeloblastic & 8 & $\begin{array}{l}6 \cdot 6 \\
2 \cdot 3\end{array}$ & $\begin{array}{l}0.7 \\
0.2\end{array}$ & $\begin{array}{l}0.29 \\
0.88\end{array}$ & 4.4 & $\begin{array}{r}42 \\
110\end{array}$ \\
\hline 4 & Myelomonocytic \{ & $\begin{array}{r}6 \\
10\end{array}$ & $\begin{array}{l}6.2 \\
5 \cdot 6\end{array}$ & $\begin{array}{l}0.2 \\
83.2 \\
1.18\end{array}$ & $\begin{array}{l}0.80 \\
0.70 \\
1.30\end{array}$ & 11 & 73 \\
\hline 5 & Myeloblastic \{ & 1 & $\begin{array}{l}3.0 \\
3.5 \\
1.7\end{array}$ & $\begin{array}{l}1.18 \\
2.8 \\
\text { None }\end{array}$ & $\begin{array}{l}1.30 \\
0.56\end{array}$ & $\begin{array}{l}10 \\
132\end{array}$ & $\begin{array}{r}102 \\
56\end{array}$ \\
\hline 6 & Myelomonocytic \{ & $\begin{array}{r}1 \\
2 \\
7\end{array}$ & $\begin{array}{l}1.7 \\
3.8 \\
4.6\end{array}$ & $\begin{array}{r}\text { None } \\
5 \cdot 28 \\
0.03\end{array}$ & $\begin{array}{l}0.30 \\
0.43\end{array}$ & $\begin{array}{l}32 \\
9 \cdot 8\end{array}$ & $\begin{array}{l}80 \\
89\end{array}$ \\
\hline 7 & Myeloblastic \{ & 4 & $\begin{array}{l}4.6 \\
3.9 \\
2.7\end{array}$ & $\begin{array}{r}0.03 \\
5.12 \\
\text { None }\end{array}$ & $\begin{array}{l}0.60 \\
0.26 \\
0.85\end{array}$ & $7 \cdot 3$ & $\begin{array}{l}97 \\
83\end{array}$ \\
\hline 8 & Lymphoblastic & $\begin{array}{l}17 \\
2 \\
8\end{array}$ & $8 \cdot 1$ & $\begin{array}{c}20 \cdot 3 \\
0.48\end{array}$ & $\begin{array}{l}0.85 \\
0.72 \\
2.90\end{array}$ & $\begin{array}{l}35 \\
9 \cdot 5 \\
26 \cdot 4\end{array}$ & $\begin{array}{l}70 \\
45 \\
60\end{array}$ \\
\hline 9 & Myelomonocytic \{ & $\begin{array}{r}2 \\
10\end{array}$ & $\begin{array}{r}120 \\
7\end{array}$ & 45 & $\begin{array}{l}0.45 \\
1.60\end{array}$ & 23 & $\begin{array}{l}45 \\
46\end{array}$ \\
\hline 10 & Myelomonocytic \{ & $\begin{array}{l}3 \\
6\end{array}$ & $\begin{array}{l}4 \cdot 5 \\
4 \cdot 3\end{array}$ & 14 & $\begin{array}{l}0.33 \\
1.80\end{array}$ & $38^{6 \cdot 5}$ & $\begin{array}{r}84 \\
190\end{array}$ \\
\hline 11 & Myeloblastic & $\begin{array}{l}6 \\
9\end{array}$ & $\begin{array}{l}4.8 \\
1.7\end{array}$ & $\begin{array}{l}\dot{5} \\
3 \cdot 4\end{array}$ & $\begin{array}{l}0.72 \\
1.08\end{array}$ & $\begin{array}{l}17 \\
72\end{array}$ & $\begin{array}{l}117 \\
134\end{array}$ \\
\hline 12 & Lymphoblastic \{ & $\begin{array}{r}8 \\
11\end{array}$ & $\begin{array}{l}5 \cdot 3 \\
7 \cdot 1\end{array}$ & $\begin{array}{r}15 \cdot 1 \\
7.9\end{array}$ & $\begin{array}{l}0 \cdot 29 \\
0.84\end{array}$ & 12 & $\begin{array}{l}41 \\
57\end{array}$ \\
\hline
\end{tabular}


A generalized aminoaciduria developed in two patients (cases 3 and 11) before cytotoxic drugs had been started. In three other patients (cases 5, 7, and 9) aminoaciduria appeared during the first course of antileukaemic therapy. Plasma amino-acids were determined in case 7 and found to be within normal limits. The pyrazinamide suppression test was used in six patients (cases $3,5,7,9,10$, and 11), and there was only a partial suppression (average $54 \%$ ) in the prepyrazinamide urinary urate excretion in three patients (cases 3, 7, and 9) and an average of $34 \%$ suppression in cases 5 and 11 . These results indicate an incomplete tubular reabsorption of urate. Case 10 showed a normal response to the administration of pyrazinamide with more than $80 \%$ reduction in urinary urate excretion.

Up to the time of writing a haematological remission was achieved in cases 3 and 5 after five and nine courses of chemotherapy respectively. Both these patients continued to receive monthly maintenance cytotoxic therapy. Serum urate increased to over $5 \mathrm{mg} / 100 \mathrm{ml}$ and there was a normal response to the pyrazinamide suppression test in both cases. The abnormal urinary amino-acid chromatographic pattern persisted in case 5 , however

Of the seven patients (cases $1,2,3,5,7,9$, and 11) showing evidence of proximal tubular dysfunction two (cases 3 and 11) developed the renal lesion before the administration of any drugs.

\section{Discussion}

Hypouricaemia was an unexpected development since in both of the patients described there was a heavy blast cell infiltration of bone marrow and, presumably, of other organs. Blast cells are a rich source of phosphorus (Rigas et al., 1956) and hyperphosphataemia has been observed after antileukaemic therapy (Zusman et al., 1973). Hyperuricaemia and hyperphosphataemia seem to be more logical sequelae to excessive destruction of tissues rich in nucleoproteins and phosphorus as a result of cytotoxic therapy.

Normally filtered urate is believed to be reabsorbed completely and $5 \%$ to $10 \%$ of the filtered load is excreted by the distal tubule (Gutman, 1964; Steele and Rieselback, 1967). Pyrazinamide, a third-line antituberculous drug, has been found to decrease tubular secretion of uric acid (Steele and Rieselbach, 1967; Gutman et al., 1969). Only about $2 \%$ of the filtered load of urate is excreted by normal persons after a single dose of $3 \mathbf{g}$ pyrazinamide. In three patients with hypouricaemia (cases 2,5 , and 11 ) this fraction exceeded $20 \%$. This finding suggests an impairment in the renal tubular reabsorption of the filtered urate.

The fall in the serum urate level in the two patients described here was associated with an increased renal clearance of urate and phosphate. Aminoaciduria developed in five of the other 10 patients studied. Plasma amino-acids were found to be within normal limits in two patients. These data indicate that impaired tubular reabsorption was the major factor responsible for the fall in the serum uric acid level.

These abnormalities outlined are seen in the adult Fanconi syndrome. Additional features associated with the syndrome but not seen in our patients are renal acidosis, glucosuria, and osteomalacia (Wallis and Engle, 1957; Leaf, 1966). The impairment of tubular reabsorption seems to involve mostly urate, phosphate, and presumably potassium-substances which are released from blast cells after effective chemotherapy. Hyperkaluria leading to hypokalaemia has been observed in $59 \%$ of the patients with acute myeloid leukaemia (to be published).

The adult Fanconi syndrome has been reported in association with various malignant states including multiple myeloma (Sirota and Hamerman, 1954) Costanza and Smoller, 1963), ovarian carcinomatosis (Clay et al., 1953), carcinoma of the pancreas (Myerson and Pastor, 1954), and carcinoma of the liver (Stowers and Dent, 1947). Hypouricaemia has been reported in patients with Hodgkin's disease (Bennett et al., 1972) and carcinoma of the lung (Weinstein et al., 1965).

The proximal tubular dysfunction with impaired tubular reabsorption, as indicated by aminoaciduria, a fall in serum urate, and an increase in phosphate clearance, seems to develop in many more patients with acute myeloid leukaemia than in any other malignant condition so far reported. A high frequency of renal tubular disturbance as seen in this series is suggestive of a causal relationship between the abnormal myeloid cells and the impairment in renal reabsorption. Muggia et al. (1969) postulated that muramidasuria might be related to hypokalaemia in patients with acute monocytic and myelomonocytic leukaemia. Hypouricaemia was not present in their patients. In one of the two patients described (case 2) the urinary muramidase concentration was within normal limits.

The renal tubular disorder can not be attributed to antileukaemic therapy since in two patients the lesion developed before the administration of these drugs and in two patients the tubular dysfunction improved during remission despite maintenance cytotoxic therapy. The most likely cause for the development of the renal tubular deficit in these patients seems to be the release of unidentified metabolites from the abnormal myeloid cells which may compete for tubular reabsorption with the normal substances in the glomerular filtrate. This view is compatible with the fact that the lesion recovered with the onset of remission in cases 1 and 3. It would also explain the observed variability in the severity of these abnormalities and the fluctuation of phosphate clearance seen in all patients.

Though not attributable to a direct toxic effect of antileukaemic therapy the hypouricaemia develops in most cases after the destruction of abnormal myeloid cells by cytotoxic drugs. Hyperuricaemia certainly occurs in some patients but the incidence of this complication in acute myeloid leukaemia is much lower than is commonly believed. Our studies on the patients presented and on other patients suggest that there is a high frequency of proximal renal tubular dysfunction, which affects reabsorption of urate, in acute myeloid leukaemia. This acts as a "safety valve" and prevents the development of hyperuricaemia.

We thank Dr. A. H. Gowenlock for his co-operation in performing the biochemical investigations, and Dr. B. Fowler and Dr. D. B. Gordon, the Willink Biochemical Genetics Laboratory, Manchester, for estimating plasma amino-acids.

\section{References}

Bennett, J. S., et al. (1972). Annals of Internal Medicine, 76, 751.

Clay, R. D., Darmady, E. M., and Hawkins, M. (1953). Fournal of Pathology and Bacteriology, 65, 551 .

Costanza, D. J., and Smoller, M. (1963). American fournal of Medicine, 34, 125.

Gold, L. G., and Fritz, R.D. (1957). Annals of Internal Medicine, 47, 428.

Gomorri, G. (1942). Fournal of Laboratory and Clinical Medicine, 27, 955.

Gutman, A. B. (1964). American fournal of Medicine, 37, 833.

Gutman, A. B., Yu, T. F., and Berger, L. (1969). American fournal of Medicine, 47, 575 .

Kritzler, R. A. (1958). American fournal of Medicine, 25, 532.

Leaf, A. (1966). In The Metabolic Basis of Inherited Disease, ed. J. B. Stanbury, J. B. Wyngaarden, and D. S. Fredrickson, 2nd edn., p. 1205. New York, McGraw-Hill.

Muggia, F. M., et al. (1969). American fournal of Medicine, 47, 351.

Myerson, R. M., and Pastor, B. H. (1954). American fournal of the Medical Sciences, 228, 378.

Nordin, B. E. C., and Fraser, R. (1960). Lancet, 1, 947.

Parry, R. M., Jun., Chandan, R. C., and Shahani, K. M. (1965). Proceedings of the Society of Experimental Medicine, 119, 384

Rigas, D. A., et al. (1956). Fournal of Laboratory and Clinical Medicine, 48, 356.

Sirota, J. H., and Hamerman, D. (1954). American fournal of Medicine, 16, 138.

Steele, T. H., and Rieselbach, R. E. (1967). American fournal of Medicine, 43, 868.

Stowers, J. M., and Dent, C. E. (1947).Quarterly fournul of Medicine, 16, 275.

homas, A. J. (1970). In Automaton, Mechanization and Data Handling in Microbiology, ed. A. Baillie, and R. J. Gilbert, p. 107. London. Academic Press.

Wallis, L. A., and Engle, R. L., Jun. (1957). American fournal of Medicine, $22,13$.

Weisberger, A. S., and Persky, L. (1953). American fournal of Medical Science, 225, 669 .

Weinstein, B., Irreverre, F., and Watkin, D. M. (1965). American fournal of Medicine, 39, 520.

Wrong, O., and Davies, H. E. F. (1959). Quarterly fournal of Medicine, 28, 259.

Zusman, J., Brown, D. M., and Nesbit, M. E. (1973). New England fournal of Medicine, 289, 1335 . 